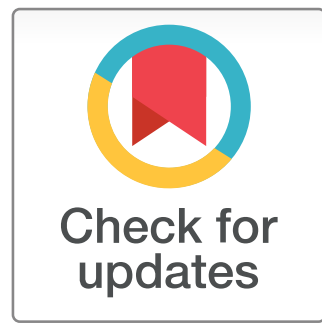

OPEN ACCESS

Citation: Sudrajat, A. R., \& Andhika, L. R. (2021). Empirical Evidence Governance Innovation in Public Service. Jurnal Bina Praja, 13(3), 407-417. https://doi.org/ 10.21787/jbp.13.2021.407-417

Received: 10 May 2021

Accepted: 22 November 2021

Published: 30 December 2021

(c) The Author(s)

\section{cc) $\$(2)$}

This work is licensed under a Creative Commons Attribution-NonCommercialShareAlike 4.0 International License.

\section{ARTICLE}

\section{Empirical Evidence Governance Innovation in Public Service}

\author{
Arip Rahman Sudrajat (D) ${ }^{1}$, Lesmana Rian Andhika (D) $2 \approx$ \\ ${ }^{1}$ Sekolah Tinggi Ilmu Administrasi Sebelas April, Sumedang \\ ${ }^{2}$ Southeast Aceh Regency Government, Kutacane \\ Dlesmana.ra@outlook.com
}

Abstract: Innovation in government activities is more directed in public services, although innovation can emphasize processes, development, planning, policies, and other activities. This research discusses governance innovation from empirical evidence that applied innovation cannot provide maximum results. The cause, government innovation that is not realized, appears only as a ceremonial act in government activities. Qualitative method analysis describes experiences, perceptions, responses through facts found in the informant's experience. This study was conducted in the Population and Civil Registration Record Office of Southeast Aceh Regency, starting from September to November 2020. In-depth interviews conducted with informants of this research consisted of government or executive, legislative, related institution, and citizen. Our field findings use the technique of hermeneutics to interpret various views that we can learn to look at the subject from every angle of knowledge (public administration, management, politics, innovation, and technology). That innovation should be supported by policies that result from decision-making, manager expertise, developed through long-term evaluation, and innovation as the basis for the quality of government public services. Governance innovation focuses on innovative action through various government instruments that lead to the simplification of action towards quality public services. For this reason, government, innovation, and how to manage are modes that continue to exist in administrative reform in government institutions with governance innovation that influence each other.

Keywords: civil registration; governance innovation; public service 


\section{Introduction}

The word 'governance' is a common word revealed to assess good governance. The use of the word governance has spread widely in various disciplines (Bevir, 2012). The theory of governance innovation is rare in the innovation and governance literature (Moore \& Hartley, 2008), conceptualizing the governance innovation and approach of innovation and governance contextually (Anttiroiko et al., 2011). In general, governance is an overall pattern of rules (Anttiroiko et al., 2011). It is the basic principle that is applied in an organization of any kind. For example, governance in government will open up and undermine the concept of the state as a monolithic entity. The current government requires governance to implement policies involving stakeholders, public participation, and collaboration to create public service. After the administrative reform in various countries happened, reform is considered a way to increase attention to the causes and consequences of the social change, mainly through the bureaucracy. This initiation occurs because of severe problems in the activities of public administration. In conditions that are always left behind to provide public services, boost the aspirations and expectations, change gives a sign that reform will always exist.

Therefore, innovation represents the novelty of doing things in a better way than ever before in public administration (Anttiroiko et al., 2011). Further innovations in the government will revitalize the role of leadership in making policies and elaborate new ideas and adoption in action. A variety of arguments says that governance innovation at least discusses elements of policymakers, managers, citizens (Hartley, 2005), democratic, managerial, development, and service function of government (Anttiroiko et al., 2011). Other elements more discuss governance innovation in the form of government policy support. Simply put, governance innovation will lead to how the government can manage innovation with innovative ways involving various elements; its purpose is only to deliver good public services.

The phenomenon of government innovation activity often aims at public services. Innovation is not correctly measured just as media change in delivering public services, but innovation aims to improve to effective performance organization (McLaughlin \& Kennedy, 2015). Innovation is not something simple with an idea and application, but how the integration process into the system results in long-term monitoring (Klimentova, 2014). However, innovation is often viewed as a new way that is better than before (Arundel \& Huber, 2013). Practitioners and academics have provided some arguments about innovation that can be learned. His ideal in government, innovation can problem-solve the issue of corruption, collusion, and nepotism contributed to the organization's performance and effectiveness (Tohidi \& Jabbari, 2012). Innovation in public service will enhance service quality (Aminah \& Wardani, 2018; de Vries et al., 2016) and improve the public's trust in the government (Cheung, 2013). Government innovations are often linked to the process of change between service providers and users. The change should also consider the process, impact, and results (Hartley, 2005). Besides governance, innovation can be entered in the form of changes (Anttiroiko et al., 2011). Therefore, governance innovation becomes one of how to manage government activity in the world ever-changing (Scupola \& Zanfei, 2016). On the other hand, there is a skeptical view of public sector innovation that will spend the government budget.

Government innovations are often linked to the process of change between service providers and users. The change should also consider the process, impact, and results (Hartley, 2005). Besides governance, innovation can be entered in the form of changes (Anttiroiko et al., 2011). Therefore, governance innovation becomes one of how to manage government activity in the world ever-changing (Scupola \& Zanfei, 2016). On the other hand, there is a skeptical view of public sector innovation that will spend the government budget. Recognized that we see there is a trend like that in local government in managing innovation. Although the new public management concept many uses the principle of private, the government does not have to fully replicate the 
private sector's principles in innovating. Even though the previous research has provided a vital study based on governance innovation, the result cannot specifically feedback policymakers and government administrators. In addition, there are more studies to discuss governance innovations in developed countries, and these findings cannot be explored extensively in a developing country like Indonesia. There is a difference that limits it, such as citizen participation that tends to not be fully democratic in government activity.

At this time, public services in the field of population and civil registration are targets for accelerated public service innovation by the Ministry of State Apparatus Empowerment and Bureaucracy Reform in addition to hospitals and district offices. Although the leaflet of Minister of Home Affairs No. 471.13/5386/SJ Year 2017 has been issued for regency/city to accelerate recording completion electronic ID card (KTP-el) and the ownership coverage of birth certificates. For example, since 2015, the population and civil registration record office of Aceh Tenggara Regency has carried out several innovations such as mobile cars to make it easier for people to get services in 16 districts because they are far from the population civil registration head office. The call center only aims to accept requests from the village through Short Message Service (SMS) and real-time calling to make the population administration document.

Mobile cars and call centers are forms of innovation that most local governments commonly carry out to provide public services in the population administration sector. But what distinguishes one from the other is how these two forms of innovation are managed innovatively. Most mobile cars for population administration services operate for data and population documents and are placed in modern shopping centers, traditional markets, and remote areas. The population and civil registration record office of Southeast Aceh Regency do the same thing but differ in mobilizing society to make the population data and documents. This method is an effort to maximize the function of the mobile car by making local cultural arts performances first, which is centered in several sub-district, so people come together. People in remote villages who cannot attend due to transportation constraints provided transportation with a "shuttle system".

Research and a report from the United Nations in 2015 on Innovative Public Service Delivery: Learning from Best Practice found that governance is a central element in public service delivery innovation. The provision of innovative public services requires strengthening the governance and capacity of the public sector, the most important of which is the institution's analysis, policy actors, and society in the governance system. Although they have carried out several innovation actions like other regions, in 2019, there were 4.168 people out of 232.089 people who had not recorded. Innovation should improve public services, improve recorded population data and documents, and diminish duplicate data. In addition, they were equalizing the rights of every citizen to get services and suppressing the occurrence of illegal levies. Therefore, for the innovation implementation to show more effective results, governance innovation is needed (Anttiroiko et al., 2011).

Some views have colored the discussion about governance innovation; several studies that have been conducted provide important information that innovation needs to be managed in a creative act. In his study, Hartley (2005) found that public sector innovation can be improved by linking and being supported by innovation, improvement, role of policymakers, role of public managers, and population. Norris (2014), in his study, highlighted innovative, collaborative, or experimental governance modes, the results of which contribute to improving accountability and effective governance models. Scupola and Zanfei (2016), in their investigation, found that governance innovation requires participatory users to achieve greater inclusiveness. In addition, they also found that public policy implications are a key factor for effective innovation in library services for the transition to network governance modes.

Although previous studies very important foundation for understanding governance innovation, this study provides a different nuance from previous studies to 
describe governance innovation. This study looks at the issue of governance innovation from the provider's perspective, users, and recipients of innovation that was not carried out by previous studies. On the other hand, governance innovation will have consequences for failure, success, and innovation implementation effectiveness (Anttiroiko et al., 2011; Hartley, 2005; Moore \& Hartley, 2008; Scupola \& Zanfei, 2016). At this point, the government provides good population administration services to the citizen as recipients.

Therefore, administrative reform is likely to impact public sector innovation (Scupola \& Zanfei, 2016). Even the administrative reform has given special priority to track changes in various ways, including the intensity of the use of information technology (Gobble, 2016). Changes in public policy (Osborne \& Brown, 2013) and governance innovation (Anttiroiko et al., 2011; Scupola \& Zanfei, 2016). Finally, our focus on governance innovation as one priority of those changes (see also Klimentova, 2014; Torfing \& Triantafillou, 2016). Anttiroiko et al. (2011) mention some concepts that refer to the application areas of governance innovation, such as democratic, managerial, development, and government service functions. Further, we will show the results of empirical investigations related to governance innovation in the sector of civil registration records.

The main goal of this research is to provide additional qualitative evidence that governance innovation needs to manage innovatively. This study provides evidence obtained from the qualitative analysis to explain, describe, and identify how governance innovation occurs. Based on a detailed review of scientific literature, analysis and synthesis of the governance innovation model will be developed. Therefore, we will first review the governance innovation model previously developed by Anttiroiko et al. (2011) and one of the models developed in this topic as a reference to approach governance innovation. Then we extend the approach by adapting the reference model to analyze empirically. Finally, we will assess and take a broader insight to implement governance innovation with the innovative activities in the sectors of civil registration records. On the other hand, this article will discuss research questions, how the model of governance innovation Anttiroiko, Bailey, and Valkama provides useful guidelines for analysis in describing civil registration records service. Also, the article will discuss the research methods, results and discussion, and conclusion.

\section{Methods}

Research methods this article is qualitative research. The analysis is used to understand experiences, perceptions, and responses by describing the facts found in the original informant's experiences (Creswell, 2013). The theoretical basis is used as a guide so that the research focus follows the field's facts. This study uses a purposeful sampling technique in finding primary information that is people, background, specific occurrence (unique, special, and strange) is chosen or included to provide important information related to the research theme (Alwasilah, 2011).

This research was conducted at the Population and Civil Registration Record Office of Southeast Aceh Regency, starting from September to November 2020. Even though it is a COVID-19 pandemic, Southeast Aceh Regency is in the yellow area category to carry out research activities. In the analysis of this research, researchers add dimension to descriptive and interpreting research data. The data was collected through inductive, interview, discussion, and observation participation. Researchers are involved in the Population and Civil Registration Record Office of Southeast Aceh Regency to observe external supervisors analyze policies, manager performance, and innovation implementation. In-depth interviews conducted with informants of this research consisted of government or executive (10 informants), legislative (5 informants), related institutions (5 informants), and citizens (10 informants). This research also refers to several last studies that serve as evidence to build and strengthen previous arguments. Informants are allowed to talk as much as possible to 
get the information needed. Provide an opportunity for them to understand the phenomenon that we asked with a different perspective. Also, we direct them to give enough information about the interpretation, experience, and knowledge they have. We use this model with the utmost caution and avoid information that leads to personal, religious, and tribal questions. We consider that question of personal, religion, and tribe is a sensitive issue in our country.

However, we use the technique of hermeneutics to interpret various views that we can learn to look at the subject from every angle knowledge (public administration, management, politics, innovation, and technology) to fully understand, and we also focus on reading to do a critical analysis. Therefore, figures, tables, and numbers are used to strengthen the research results, besides triangulation is also applied to validate data. So that we can compare and check the credibility level of information obtained through different times and tools so that perfection is found that expected data.

\section{Results and Discussion}

\subsection{Civil Registration Record in Indonesia Experience}

Indonesia experienced a transformation of civil registration records as a recordkeeping effort continues to evolve. From the colonial period until 2011's called National ID cards, and in that period still using civil registration records manually. Change of paper, colors, different sizes used as an attempt at transformation. However, data recorded often causes inaccurate data because the record-keeping system was still concentrating on the local level and not yet integrated nationally. In February 2011, the government of Indonesia created uniformity nationwide by utilizing electronic (e-ID), which is considered anti-manipulation data.

e-ID Cards applied by Indonesia have an advantage compared to countries such as China and India. China uses only the chip data of individuals without biometric data. India using system UID (Unique Identification Data) for data management is done through a hotspot service is limited. However, e-ID cards (KTP-el) Indonesia combines the excess other, i.e., chip as individual data, biometric (fingerprint and iris eyes) and UID (UID, the unique of number family registration), and the recording process is more than 6.214 sub-district at Indonesian. Because the e-ID Card has several advantages as a single identity and anti-manipulation, its use has also spread as a condition for various things in other institutions such as banks, social security, and election.

\subsection{Empirical Investigation}

Further, we will show the results of empirical investigations related to governance innovation in the sector of civil registration records. This paper refers to the framework of governance innovation concepts from Anttiroiko, Bailey, and Valkama. We consider

Figure 1. Innovation Concepts in the Field of Public Governance

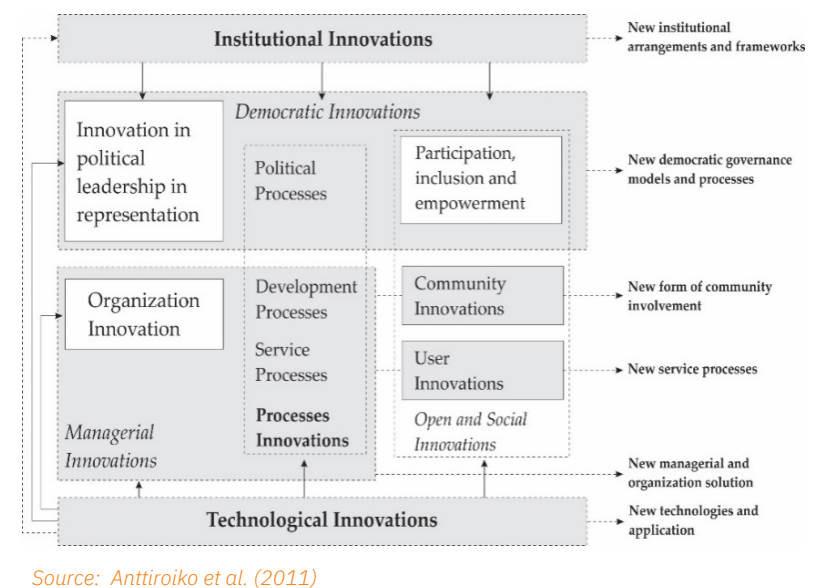

Source: Anttiroiko et al. (2011) 
Table 1. Democratic Factor

this concept to describe governance innovation comprehensively and its implications for some other sectors. Anttiroiko et al. (2011) identify four factors of governance innovation concepts because of a relation between democratic, managerial, development, and government service functions. Innovation governance factor to reflect the above visualized in Figure 1.

In Figure 1, we try to find responses to the informant about the factor it with notice at the pattern of coherence, an indicator of some subject on public administration, management, politics, innovation, and technology science.

\subsubsection{Democratic}

Democratic in view Anttiroiko et al. (2011) refer to the mechanism of the political process to result in the policy. Local government leadership will be instrumental in building relational politics to execute programs that have been designed before, but in the conception of innovation, leadership must be a transformational leader. Further citizen participation is needed because they are the objects of all government activities. The results of our research analysis are illustrated in Table 1.

\begin{tabular}{clcccc} 
Factor & \multicolumn{1}{c}{ Pattern } & Executive & Legislative & Civil Society & Citizen \\
Democratic & $\begin{array}{l}\text { Political processes, } \\
\text { political } \\
\text { leadership, citizen } \\
\text { participation }\end{array}$ & $\begin{array}{l}\text { Policy, material, or } \\
\text { human resources }\end{array}$ & Policy, financing & $\begin{array}{l}\text { Public policy } \\
\text { feasibility test }\end{array}$ & Participation \\
\hline
\end{tabular}

New Democratic Governance Model and Processes; New Form Community Involvement

Source: Anttiroiko et al. (2011) and researcher analysis (2020)

Field finding in Table 1 shows that political processes, political leadership, and citizen participation provide implications to the new democratic governance models and processes. However, in our investigation of the existing patterns, we cannot fully demonstrate a new process model in governance innovation. For example, a political process that is not good shows that political intervention in bureaucracy will lead to various problems such as increasingly widespread bureaucracy pathology. Maybe has caused by the pattern of patronage and clientelism in the regional head election. The fact is that there is a blocking of population services due to the bureaucrat mutation without any coordination with the central government.

On the other hand, the head of the department still retains the traditional values and considers themselves as people who should be served and not served. Political leadership is not only a leader who serves as the ruler or understands the political process. Leadership in this domain considers the complexities of environmental adaptation with relational politics. Further, the general role is performed by political leaders in the form of an executive role, supervision, and regulation. We see such circumstances will inhibit the policy production, budget allocation, and the innovation program's planning because the policy is a hint to every government activity. Leadership is a manifestation of how much the leader will side with the citizen, and the taking values sides for the welfare of society, and how much politics will show him to the people's proximity. A leader can mobilize all the attributes attached to himself. Authority makes it easier for a leader to find the problem root identified or not in government activities.

Furthermore, a leader must encourage himself to take transformational steps. Therefore, the conception of innovation says that transformational leadership will enhance creativity, citizen participation, and culture across traditional organizational boundaries by managing knowledge to increase with creative ideas. Bryson et al. (2013) argue the conception of public administration mentioned citizen participation in the interaction between citizen and administrative decisions, public policy, and public service. For that government and citizens will achieve the polycentric decisionmaking model, citizen participation is often expressed through various government 
Table 2. Managerial Factor

policies but rarely implemented. Further citizen participation indirectly will promote acceptance rates against various forms of government innovation.

\subsubsection{Managerial}

Managerial activities involve the ability of knowledge management. Managerial functions include planning and involve setting goals to achieve them. Further planning is considered the main management function, covering everything done and contributing to other management functions. Therefore, we search and focus on the managerial ability to manage cross-border cooperation, innovation development, and service process. The results of our research analysis are illustrated in Table 2.

\begin{tabular}{clllll} 
Factor & \multicolumn{1}{c}{ Pattern } & Executive & Legislative & Civil Society & Citizen \\
Managerial & $\begin{array}{l}\text { Cross-border } \\
\text { cooperation, } \\
\text { innovation } \\
\text { development, } \\
\text { service processes }\end{array}$ & $\begin{array}{l}\text { Delegation of } \\
\text { authority }\end{array}$ & Controlling & $\begin{array}{l}\text { Based research } \\
\text { policy }\end{array}$ & $\begin{array}{l}\text { Bottom-up } \\
\text { boundaries }\end{array}$ \\
\hline
\end{tabular}

New Managerial and Organization Solution

Source: Anttiroiko et al. (2011) and researcher analysis (2020)

Field finding from managerial factor found that managerial ability not only plans but also manage interpersonal skills, conceptual ability, cooperation, and politics. For example, cross-border cooperation implicitly and explicitly is cooperating with others to achieve organizational goals. Not only in cooperation with government institutions but the private sector can be involved and manage cooperation. Advertising on local television, local radio, local news portals will provide education benefits, and information dissemination will be evenly distributed. The fact that such cooperation is not implemented due to budget constraints. Therefore, cross-border cooperation will enhance achievement objectives together. Meanwhile, the influence of various policies, political processes, budget, human resources, and leadership contributes to the innovation implementation development further. Usually, innovations that are contrary to work and intricate culture will be difficult to develop.

Another example of the service process, the results of our analysis show that the innovation process in service refers to new products, even though the service process can have technology elements, technique, or skill. The development of new public services is closely related to design and service development. This diversity means that generalizations about service and innovation must be qualification by the many exceptions. At this point, the manager should focus on surveillance, creating opportunities between government and society with a relationship of mutual trust across borders, developing and implementing alternative solutions.

Denhardt and Denhardt (2015) mention the conception of the new public service mentioned employees could not be accurately described only in response to the demands of "customers" as a fast and efficient solution. The heterogeneity of managers in government institutions is a bit less concerned about many governance innovation aspects. Some literature mentions related positive managerial ability against the quantity and quality of innovation. The manager will be the internal change agent, specifically a role changes to adopt various innovations in an organization to increase efficiency. Managers have a greater influence to improve the capacity for structure innovation, processes, and contextual factors that drive innovation (Lewis et al., 2018).

\subsubsection{Development}

The development also can be done by citizen involvement, but the existing literature reveals a mixed view about the uncertain effects of technology and citizen engagement in the developing new services process. Tools used in general to develop 
Table 3. Development Factor

\begin{tabular}{clllll} 
Factor & \multicolumn{1}{c}{ Pattern } & Executive & Legislative & Civil Society & Citizen \\
\hline Development & $\begin{array}{l}\text { Technology, } \\
\text { innovation } \\
\text { processes }\end{array}$ & $\begin{array}{l}\text { Material or human } \\
\text { resources }\end{array}$ & Policy diffusion & $\begin{array}{l}\text { Based on research } \\
\text { policy and } \\
\text { research } \\
\text { collaboration }\end{array}$ & $\begin{array}{l}\text { Response to } \\
\text { innovation }\end{array}$ \\
\hline
\end{tabular}

New Technology and Application

Source: Anttiroiko et al. (2011) and researcher analysis (2020)

innovation by leveraging technology and see the extent innovation process can lead to development. The results of our research analysis are illustrated in Table 3.

Field findings from the development factor emphasize that utilization of technology will make system integration easier among several sections in the organization and distribute knowledge almost inevitable from the change organization environment. When compared with technological advancement, technology becomes a government transformation tool between users and service providers, and innovation has opportunities. However, the integration of the population technology system has not yet reached all sub-districts and is only integrated into national systems such as health and general elections. Because it is in the district where the population database is located, some of the institutions that use technology are: First, direct the institutions to more easily take on challenges and demands of an increasingly complex society. Second, as a means of interaction between government and citizens. In this case, we see that the lack of collaboration between various authorities can stop innovation adoption. However, the same policy that does not exist, limitation knowledge, also contributes to why process innovation is difficult to implement.

On the other hand, the innovation process involves several organizational elements that will develop into innovation and is the innovation cycle process. Innovation requires the organization's collaborative process to abandon the old paradigm and move on to a new paradigm. The innovation process also covers imaginative idea conjures to stage evaluation. Results of the study found that creative ideas are often not used for some reasons such as just maybe the negative impact idea, it does not provide many advantages, and the idea was deemed impossible. Further, innovative ideas cannot be helping organizations, but rather the innovation should test and implement an innovative act to know its benefits. In this case, we see that the lack of collaboration between various authorities can stop innovation adoption. However, the same policy that does not exist, limitation knowledge, also contributes to why process innovation is difficult to implement.

Suárez-Barraza (2013), in his study, reveals that the innovation process is done gradually in the Spanish local government by growing desire and leadership commitment of the region, legislators (politicians), and the bureaucratic apparatus to do innovation. Other arguments also reveal that the innovation process will affect management and organization (Walker, 2014). On the other hand, the innovation process is also a means of action, processing, or producing products (Alekseevna, 2014; McLaughlin \& Kennedy, 2015). The most rational thing about innovation can actualize an idea to become a successful concept. It is necessary for a good understanding of the process and supports this will distinguish successful innovation processes from innovations that fail.

\subsubsection{Service Function of Government}

One main functions of government were to remain in power, but the government will not relinquish its obligations, will attempt to improve legitimacy in various ways, and recognize the principle that the public should be protected and catered to. Our focus is on the administrative service design of civil registration records. It is hoped to give an idea that various models adopted. The results of our research analysis are illustrated in Table 4. 
Table 4. Service Function of Government

\begin{tabular}{llllll}
\multicolumn{1}{c}{ Factor } & \multicolumn{1}{c}{ Pattern } & Executive & Legislative & Civil Society & \multicolumn{1}{c}{ Citizen } \\
$\begin{array}{l}\text { Service Function of } \\
\text { Government }\end{array}$ & $\begin{array}{l}\text { Design of } \\
\text { innovation, user } \\
\text { innovation }\end{array}$ & $\begin{array}{l}\text { Model design } \\
\text { implementation }\end{array}$ & Policy diffusion & $\begin{array}{l}\text { Based on research } \\
\text { policy and } \\
\text { research } \\
\text { collaboration }\end{array}$ & $\begin{array}{l}\text { Response to } \\
\text { innovation }\end{array}$ \\
\hline
\end{tabular}

New Service Processes

Source: Anttiroiko et al. (2011) and researcher analysis (2020)

This study found that public service will consider designing user services as core values within public service. Furthermore, in government activity, public service model designing actions are inseparable from equal budgetary policies and legislative support, especially executives. Designing product services can be done in some ways exploit regional innovation agencies and research with educational institutions. The executive side of the balance between soft and hard skills should be used as a valuable instrument in bringing up someone's creativity.

Innovation culture in an organization will appear when all individuals are given the same opportunity to consistently seek new ways that go beyond their limits of ability. The object government services are a citizen, but in the good governance concept, citizen participation as a user and the recipient becomes the important thing, how the city is giving feedback on that service model on its own. Citizens are conditioned as users and recipients of government services. They do not have the option to get a quality choice, type, quantity, and how to acquire it because it has been government regulated. Therefore, the concept of public service is often equated with the service provided by the government with monopoly rules, organizing, products, distribution, and monitoring.

In addition, the findings of this study are that the process of public service in the Population and Civil Registration Record Office of Aceh Tenggara Regency has not been following the objectives. Concerning innovation, the low competence of human resources will result in no significant changes in public service. This means that the service designed by the government cannot be developed by the Population and Civil Registration Record Office of Aceh Tenggara Regency to improve the efficiency and quality of public services because each region has differences due to culture, social, and resources. It takes cooperation and an adaptive team to translate the design of public services required by the government.

Further our findings from some literature teach that to design innovative services can be done by involving citizen participation (Sinni, 2017), experience the giver as well as the service users (Trischler \& Scott, 2016), and collaboration with various parties, including the private sector (Yu \& Sangiorgi, 2018). The executive side of the balance between soft and hard skills should be used as a valuable instrument in bringing up someone's creativity. Innovation culture in an organization will appear when all individuals are given the same opportunity to seek new ways effectively consistently that go beyond the limits of ability they have (Zennouche et al., 2014). The object government services are a citizen, but in the good governance concept, citizen participation as a user and the recipient becomes the important thing, how the city is giving feedback on that service model on its own. Citizens are conditioned as users and recipients of government services. They do not have the option to get a quality choice, type, quantity, and how to acquire it because it has been government regulated. Therefore, the concept of public service is often equated with the service provided by the government with monopoly rules, organizing, products, distribution, and monitoring.

\subsection{Managing Innovation}

From the results of our research, policy analysis, leadership, process innovation, development, and design of service models did not show the real support for 
performing various innovations. Citizen participation is often considered less useful in government activities due to the limited knowledge required or less democratic societies. Another thing with other local governments such as Padang Pariaman, and Surakarta, Klungkung Regency, Badung Regency, Situbondo Regency, Tanah Datar Regency, these areas have their special way to improve support for innovation. Start building trust between legislative and executive branches to produce policies, improving the capacity of knowledge leaders about innovation through education, training in collaboration with the university, forming research together, and collaboration with the private sector. Besides, the most important point in our opinion is how innovation is managed innovatively.

For local governments that minimal budgets cannot use advanced information technology. However, some local governments in Indonesia use different instruments to be a new option that is objective (Aminah \& Wardani, 2018; Hutagalung \& Hermawan, 2018). However, on the good side, the management and development of innovation in the Population and Civil Registration Record Office of Aceh Tenggara Regency are improved by local government policies. Such as planning and designing innovations with other institutions, budget allocation, integrated short message service (SMS) the whole district, monitoring, and evaluation. Innovations may give rise to advantages both in individual, group, organization, or the wider community. Thus, the balance between the different governance paradigms will increase the production of public innovation and bring new solutions that will have outperform the existing ones (Torfing \& Triantafillou, 2016).

\section{Conclusion}

From some factors that became the analysis, it was found that almost all factors indicated that the governance innovation of public service still needed improvement, clear goals, and perceptions from employees, especially in the democratic and development factor. When politics excessively intervene in the bureaucracy, it will lead to some bureaucratic pathologies. This situation is often encountered if the placement of a leader is not based on competence which will result in poor mechanisms and ways of leading. So, in addition, must the ability of managers to pay attention to the ability of interpersonal skills, conceptual ability, cooperation, and politics. Innovation development is needed from time to time to see the deficiency of innovation, impact, and solutions for the integrated technology to operate. Likewise, with the government providing public services, service design needs to adopt new ways so that high efficiency.

Furthermore, our analysis has made it possible to identify extension frameworks Anttiroiko, Bailey, and Valkama. First, we argue that because this concept operates in western countries, expectations of this framework are much lower when applied to the condition of local governments that were less concerned with the public services quality. Second, the concept of Anttiroiko, Bailey, and Valkama is very helpful to know how to manage innovation by various government instruments. We are aware that this research can be increased again the better. Therefore, we suggest to future researchers to investigate various instruments of governance innovation in government activity because we believe that innovation with implementing the management procedure will improve the quality of the public services.

Acknowledgment

Any party that did not sponsor this study, and thanks to all those who have participated, provided information so that this research can be realized. For this reason, researchers feel the need again to develop knowledge in the future with review and analysis from this article.

References

Alekseevna, M. A. (2014). Evolution of the Innovation Process Models. International Journal of Econometrics and Financial Management, 2(4), 119-123. https://doi.org/10.12691/ijefm-2-4-1

Alwasilah, A. C. (2011). Pokoknya Kualitatif: Dasar-dasar Merancang dan Melakukan Penelitian Kualitatif (6th ed.). Dunia Pustaka Jaya. 
Aminah, S., \& Wardani, D. K. (2018). Readiness Analysis of Regional Innovation Implementation. Jurnal Bina Praja, 10(1), 13-26. https://doi.org/10.21787/jbp.10.2018.13-26

Anttiroiko, A.-V., Bailey, S. J., \& Valkama, P. (Eds.). (2011). Innovations in Public Governance. IOS Press BV.

Arundel, A., \& Huber, D. (2013). From too little to too much innovation? Issues in measuring innovation in the public sector. Structural Change and Economic Dynamics, 27(C), 146-159. https://doi.org/10.1016/ j.strueco.2013.06.009

Bevir, M. (2012). Governance: A Very Short Introduction. OuP Oxford.

Bryson, J. M., Quick, K. S., Slotterback, C. S., \& Crosby, B. C. (2013). Designing Public Participation Processes. Public Administration Review, 73(1), 23-34. https://doi.org/10.1111/ j.1540-6210.2012.02678.x

Cheung, A. B. L. (2013). Public governance reform in Hong Kong: rebuilding trust and governability. International Journal of Public Sector Management, 26(5), 421-436. https://doi.org/10.1108/ IJPSM-05-2013-0070

Creswell, J. W. (2013). Qualitative Inquiry and Research Design: Choosing Among Five Approaches. SAGE.

de Vries, H., Bekkers, V., \& Tummers, L. (2016). Innovation in the Public Sector: A Systematic Review and Future Research Agenda. Public Administration, 94(1), 146-166. https://doi.org/10.1111/padm.12209

Denhardt, J. V., \& Denhardt, R. B. (2015). The New Public Service Revisited. Public Administration Review, 75(5), 664-672. https://doi.org/10.1111/puar.12347

Gobble, M. M. (2016). How Government Innovates. Research-Technology Management, 59(2), 62-67. https://doi.org/10.1080/08956308.2015.1137188

Hartley, J. (2005). Innovation in Governance and Public Services: Past and Present. Public Money \& Management, 25(1), 27-34. https://doi.org/10.1111/j.1467-9302.2005.00447.x

Hutagalung, S. S., \& Hermawan, D. (2018). Evaluation of Local Government Innovation Program in Lampung Province. Jurnal Bina Praja, 10(2), 241-250. https://doi.org/10.21787/jbp.10.2018.241-250

Klimentova, S. (2014). Innovation in the public sector: Is it measurable? In Performance Measurement and Management Control: Behavioral Implications and Human Actions (Vol. 28, pp. 289-315). Emerald Group Publishing Limited. https://doi.org/10.1108/S1479-351220140000028021

Lewis, J. M., Ricard, L. M., \& Klijn, E. H. (2018). How innovation drivers, networking and leadership shape public sector innovation capacity. International Review of Administrative Sciences, 84(2), 288-307. https://doi.org/10.1177/0020852317694085

McLaughlin, G. C., \& Kennedy, W. R. (2015). A Guide to Innovation Processes and Solutions for Government. CRC Press. https://doi.org/10.1201/b18841

Moore, M., \& Hartley, J. (2008). Innovations in governance. Public Management Review, 10(1), 3-20. https:/ /doi.org/10.1080/14719030701763161

Norris, J. J. (2014). Rethinking accountability in new governance. Innovation: The European Journal of Social Science Research, 27(3), 199-219. https://doi.org/10.1080/13511610.2014.943165

Osborne, S., \& Brown, L. (2013). Handbook of Innovation in Public Services. In S. Osborne \& L. Brown (Eds.), Handbook of Innovation in Public Service. Edward Elgar Publishing. https://doi.org/ 10.4337/9781849809757

Scupola, A., \& Zanfei, A. (2016). Governance and innovation in public sector services: The case of the digital library. Government Information Quarterly, 33(2), 237-249. https://doi.org/10.1016/j.giq.2016.04.005

Sinni, G. (2017). Participatory Design for Public Services. Innovation in Public Administration. The Design Journal, 20(sup1), S3368-S3379. https://doi.org/10.1080/14606925.2017.1352841

Suárez-Barraza, M. F. (2013). Process Innovation in Local Governments: an empirical study of continuous improvement effort. Review of Business Management, 15(47), 204-220. https://doi.org/10.7819/ rbgn.v15i47.1160

Tohidi, H., \& Jabbari, M. M. (2012). Innovation as a Success Key for Organizations. Procedia Technology, 1, 560-564. https://doi.org/10.1016/j.protcy.2012.02.122

Torfing, J., \& Triantafillou, P. (2016). Enhancing Public Innovation by Transforming Public Governance (J. Torfing \& P. Triantafillou (Eds.)). Cambridge University Press. https://doi.org/10.1017/ CB09781316105337

Trischler, J., \& Scott, D. R. (2016). Designing Public Services: The usefulness of three service design methods for identifying user experiences. Public Management Review, 18(5), 718-739. https://doi.org/ 10.1080/14719037.2015.1028017

United Nations. (2015). Innovative Public Service Delivery: Learning from Best Practices.

Walker, R. M. (2014). Internal and External Antecedents of Process Innovation: A review and extension. Public Management Review, 16(1), 21-44. https://doi.org/10.1080/14719037.2013.771698

Yu, E., \& Sangiorgi, D. (2018). Service Design as an Approach to Implement the Value Cocreation Perspective in New Service Development. Journal of Service Research, 21(1), 40-58. https://doi.org/ $10.1177 / 1094670517709356$

Zennouche, M., Zhang, J., \& Wang, B. W. (2014). Factors influencing innovation at individual, group and organisational levels: a content analysis. International Journal of Information Systems and Change Management, 7(1), 23. https://doi.org/10.1504/IJISCM.2014.065052 